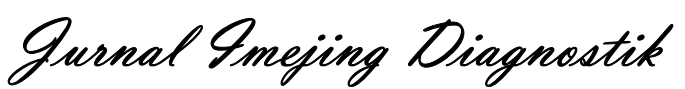

e-ISSN 2621-7457, p-ISSN 2356-301X

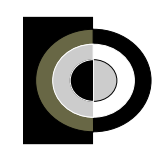

http://ejournal.poltekkessmg.ac.id/ojs/index.php/iimed/index

\title{
Pemeriksaan Os Cruris dengan Proyeksi Modifikasi Pada Kasus Fraktur
}

\author{
Kus Endah Aryati ${ }^{1}$, Sri Sugiarti ${ }^{2}$ \\ ${ }^{1,2}$ Progam Studi DIII Radiodiagnostik dan Radioterapi STIKes Widya Cipta Husada, Indonesia \\ Corresponding author: Kus Endah Aryati \\ email: kusendaharyati@gmail.com
}

Received: September 29 $9^{\text {th }}, 2020$; Revised: January $31^{\text {st }}, 2021$; Accepted: February $1^{\text {st }}, 2021$

\begin{abstract}
Background: Os cruris examination technique with modification projections is usually done in patients with fracture cases.

Methods: This study aims to determine the results of the positioning, examination techniques, and radiograph results of the os cruris examination technique with projected modifications in fracture cases. The design of this research is descriptive research with a case study approach. In the case of research fractures using 4 samples and data collection by observation, checklist, documentation, and interviews. Results: the os cruris examination technique with projected modification in fracture cases can already diagnose well but does not produce true lateral radiographs.

Conclusions: Projection modification is done if there is a fracture in the os cruris area in a noncooperative patient so that it can provide more optimal radiographic results and the patient will be more comfortable when positioned.
\end{abstract}

Keywords: os cruris; modified; fracture.

\section{Pendahuluan}

Pemanfaatan sinar-X untuk mendiagnosis suatu penyakit dilakukan dengan cara pemeriksaan radiologi, salah satunya pemeriksaan os cruris. Pemeriksaan os cruris merupakan salah satu pemeriksaan radiologi tanpa menggunakan media kontras. Indikasi pada os cruris yang sering terjadi adalah fraktur. Fraktur adalah dicontinuitas dari jaringan tulang (patah tulang) yang biasanya disebabkan oleh adanya kekerasan yang timbul secara mendadak. Fraktur tibia dan fibula adalah trauma dari kebanyakan organ ekstremitas bawah, terutama fraktur tibia dan fibula (Arafah, 2019; Whitley et al., 2015).

Penyebab paling utama fraktur tibia biasanya disebabkan oleh benturan atau trauma langsung pada tulang, antara lain kecelakaan lalu lintas atau jatuh (Maulana, 2015). Data BPS Provinsi Jawa Timur mencatat bahwa selama tiga tahun berturutturut, Jawa Timur menjadi provinsi dengan jumlah kecelakaan lalu lintas tertinggi di Indonesia Pada tahun 2016, tercatat jumlah kecelakaan lalu lintas di Jawa Timur sebanyak $106 \quad 644$ kasus. Selanjutnya, pada tahun 2017 menjadi 104327 kasus dan pada tahun 2018 sebanyak 109215 kasus kecelakaan (Badan Pusat Statistik, 2018).

Pemeriksaan cruris di beberapa rumah sakit menggunakan proyeksi Antero Posterior (AP), dan Lateral. Proyeksi AP Proyeksi Lateral merupakan sebuah anatomi untuk struktur terjauh dari garis pertengahan tubuh (Sandstrom, 2011). Sedangkan di lapangan proyeksi lateral pada pemeriksaan cruris pasien kecelakaan lalu lintas sulit diposisikan karena daerah suspect fraktur tidak bisa digerakkan. Hal ini akan mengganggu kenyamanan pasien (Rasad, 2018).

Umumnya kecelakaan lalu lintas mengalami pada daerah ekstremitas cruris, sehingga radiografer kesulitan dalam memposisikan pasien yang non kooperatif ini (Bontrager \& Lampignano, 2014). Radiografer dapat mengambil langkah dalam memposisikan pasien non kooperatif dengan memodifikasi proyeksi acuan anterior posterior dan lateral sehingga pasien bisa senyaman mungkin, dan memberikan hasil radiograf yang maksimal.

\section{Metode}

Penelitian yang dilakukan oleh peneliti termasuk penelitian deskriptif dengan pendekatan studi kasus. Penelitian studi kasus adalah suatu metode penelitian yang dilakukan dengan tujuan membuat gambaran atau mendiskripsikan tentang suatu keadaan secara obyektif (Imron \& Munif, 2010). Teknik pemeriksaan radiografi Os cruris merupakan teknik pemeriksaan untuk melihat tulang tibia dan fibula. Proyeksi yang digunakan pada teknik pemeriksaan radiografi Os cruris pada teori menggunakan true lateral (Bontrager \& 
Lampignano, 2014) akan tetapi pada RSU Aminah menggunakan proyeksi Modifikasi.

Penelitian ini dilaksanakan mulai bulan MaretJuni 2019 di Instalasi Radiologi RSU Aminah Blitar. Populasi pada penelitian ini yaitu pasien yang datang ke Instalasi Radiologi dengan pemeriksaan $O s$ Cruris pada kasus fraktur dengan jumlah sampel berjumlah 4 orang. Analisis dimulai dengan melakukan pengolahan data yang diperoleh melalui observasi, dokumentasi, cheklist, dan wawancara secara langsung tentang teknik pemeriksaan Os cruris dengan proyeksi modifikasi pada kasus fraktur di RSU Aminah Blitar.

\section{Hasil dan Pembahasan}

Hasil penelitian pemeriksaan os cruris dengan proyeksi modifikasi pada kasus fraktur yang dilakukan di RSU Aminah Blitar dilakukan sudah sesuai dengan prosedur, dimulai dari pasien datang ke IGD. Kemudian permintaan foto dari dokter dikirim ke radiologi untuk mendaftar diberi nomor registrasi foto, nama, umur, jenis kelamin, tanggal lahir, dan alamat.

Pasien yang bersedia menjadi sampel diberikan surat persetujuan menjadi sampel, setelah itu radiografer melakukan identifikasi pasien sebelum memasuki ruang foto. Identifikasi pasien perlu dilakukan karena pasien yang datang tidak hanya sedikit dan bertujuan untuk mencocokkan data pasien dan jenis pemeriksaan dengan benar. Kemudian pasien dipersilahkan masuk ke ruang foto dan diberi penjelasan tentang jalannya pemeriksaan. Setelah diberi penjelasan pasien diminta melepaskan benda-benda yang dapat mengganggu gambaran radiograf. Persiapan alat yang terdiri dari pesawat sinar-X, ketika alat sudah dipersiapkan lalu pasien diposisikan $A P$ dengan pengganjal setinggi kurang lebih $5 \mathrm{~cm}$ tujuannya agar bayangan cruris masuk ke dalam kaset sehingga gambaran cruris tercover mulai dari knee joint sampai dengan ankle joint, kemudian kaset diletakkan diantara cruris sisi medial dan sisi lateral tubuh dengan batas atas knee joint dan bawah ankle joint. Cruris diatur sehingga tibia dan fibula. Apabila pemeriksaan sudah cukup setelah itu pasien diberi penjelasan untuk pengambilan hasil fotonya setelah dibacakan dokter radiolog.

Setelah dilihat dari hasil jalannya pemeriksaan proyeksi modifikasi sudah cukup untuk menegakkan diagnosa. Anatomi yang terlihat pada sampel 1 yaitu Tibia, fibula, dan medial malleolus, anatomi yang terlihat pada sampel 2 yaitu tibia, fibula dan medial condyle dan sedangkan anatomi yang terlihat pada sampel 3 dan 4 yaitu tibia dan fibula. Proyeksi modifikasi dilakukan apabila ada fraktur di daerah cruris pada pasien non kooperatif sehingga dapat memberikan gambaran radiograf lebih optimal dan pasien akan lebih nyaman saat diposisikan. Faktor eksposi yang digunakan untuk sampel yaitu tegangan tabung $50-63 \mathrm{kV}$, dan waktu 4-6,3 s. Faktor eksposi dipengaruhi ketebalan objek sehingga daya tembus sinar-X itu akan menghasilkan gambaran yang lebih jelas. Berdasarkan data hasil cheklist sesuai dengan pernyataan responden R1, R2, R3 dan R4 yaitu Teknik Pemeriksaan os cruris dengan proyeksi modifikasi pada kasus fraktur di RSU Aminah Blitar mulai dari persiapan pasien, persiapan alat, proteksi radiasi, posisi pasien, posisi objek, Central Ray dan Center Point sudah sesuai tetapi salah satu dari responden hasil cheklist menyatakan " terkadang radiografer lupa tidak memakai TLD ( Thermoluminisence Dosemeter ) padahal sudah tersedia " maka dari itu salah satu responden menyatakan tidak sesuai untuk proteksi radiasi berupa TLD (Thermoluminisence Dosemeter ) yang terkadang radiografer lupa untuk memakai TLD (Thermoluminisence Dosemeter ) saat melakukan pemeriksaan meskipun TLD (Thermoluminisence Dosemeter ) sudah tersedia.

Berdasarkan data hasil wawancara sesuai dengan pernyataan responden R5, R6 dan R7 yaitu proyeksi modifikasi tersebut dilakukan pada pasien non kooperatif yang mengalami fraktur dan apabila pasien benar-benar tidak mampu memfleksikan knee hingga membentuk posisi true lateral. Oleh karena itu sangat penting menjalin komunikasi efektif misalnya penggunaan bahasayang baik dan benarserta mudah dimengerti oleh pasien (Menteri Kesehatan, 2020). Harapannya pasien paham tujuan dan fungsi dari pemeriksaan tersebut sehingga dihasilkan radiograf yang bagus dan dapat menegakkan diagnose. Pasien dengan kondisi fraktur pada daerah cruris akan merasa lebih nyaman dan tidak mengalami kesakitan apabila menggunakan proyeksi modifikasi. Kriteria hasil radiograf yng baik pada teknik pemeriksaan os cruris dengan proyeksi modifikasi pada kasus fraktur yaitu tampak os fibula dan tibia, tampak gambaran knee joint dan ankle joint, apabila tidak bisa menampakkan semua yang harus ditampakkan salah satu sendi tergantung fraktur pada cruris. Tujuan dari teknik pemeriksaan os cruris dengan proyeksi modifikasi pada kasus fraktur untuk kenyaman pasien jika pasien tidak bisa diposisikan lateral, memudahkan pasien pada saat pemeriksaan, pada kasus fraktur. 


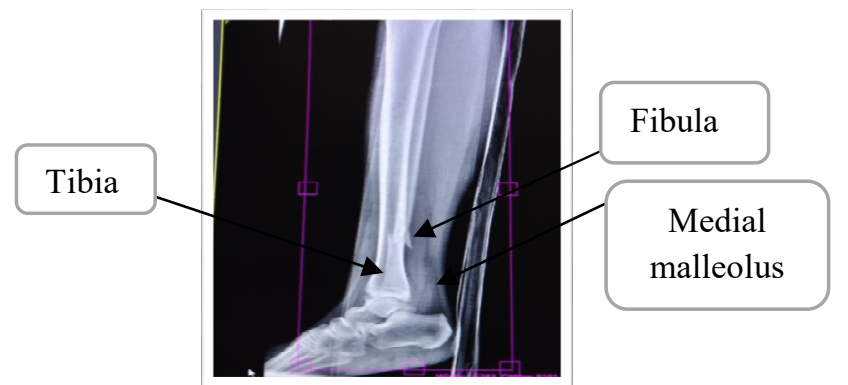

Gambar 1. Radiograf os cruris proyeksi modifikasi

Kelebihan pada teknik pemeriksaan os cruris dengan proyeksi modifikasi pada kasus fraktur gambar 1 yaitu pasien tidak kesakitan pada saat diposisikan, memberi kenyaman pada pasien, dan mempermudah jalannya pemeriksaan berlangsung. Kekurangan pada teknik pemeriksaan os cruris dengan proyeksi modifikasi pada kasus fraktur yaitu tidak dapat menghasilkan hasil radiograf yang true lateral, karena harus ada yang mengganjal kaset pada saat ekspose berlangsung.

\section{Simpulan}

Berdasarkan hasil penelitian disimpulkan bahwa hasil radiograf teknik pemeriksaan $O s$ Cruris Dengan Proyeksi Modifikasi Pada Kasus Fraktur Di RSU Aminah Blitar bahwa jumlah dari sampel berjumlah 4 , Proyeksi modifikasi pada pemeriksaan os cruris sudah bisa menegakkan diagnosa tetapi kurang untuk dapat menghasilkan hasil radiograf yang true lateral. Berdasarkan hasil dari kriteria radiograf pemeriksaan os cruris dengan kasus fraktur yaitu terlihat jelas os fibula dan tibia, tampak gambaran knee joint dan ankle joint. Proyeksi modifikasi dilakukan jika ada fraktur di daerah cruris pada pasien non kooperatif sehingga dapat memberikan gambaran radiograf lebih optimal dan pasien akan lebih nyaman saat diposisikan.

Berdasarkan hasil penelitian, maka peneliti menyarankan sebaiknya untuk pemeriksaan os cruris dengan proyeksi modifikasi pada kasus fraktur pada kondisi emergency dengan pasien non kooperatif yang benar-benar tidak mampu memfleksikan daerah knee sebaiknya menggunakan proyeksi modifikasi sehingga pasien tidak merasa kesakitan selama pemeriksaan dan pasien merasa nyaman pada saat diposisikan.

\section{Daftar Pustaka}

Arafah, M. (2019). Fraktur Tibial Plateau Posterior; Klasifikasi Three Column Concept dan Tantangan Approach operasi. Saintika Medika, 15(1), 41. https://doi.org/10.22219/sm.Vol15.SMUMM 1.8095

Badan Pusat Statistik. (2018). Statistik Transportasi Darat 2018 (Subdirektorat Statistik Transportasi (ed.)). BPS RI.

Bontrager, K. L., \& Lampignano, J. P. (2014). Textbook of Radiographic Positioning and Related Anatomy (8th ed.). Elsevier Mosby.

Imron, M., \& Munif, A. (2010). Metodologi Penelitian Bidang Kesehatan: Bahan Ajar Untuk Mahasiswa. Sagung Seto.

Maulana, R. (2015). Tibial Stress Fracture. Jurnal Kesehatan Syiah Kuala, 5(1), 60-65.

Menteri Kesehatan. (2020). Keputusan Menteri Kesehatan Republik Indonesia Nomor HK.01.07/MENKES/316/2020 tentang Standar Profesi Radiografer.

Rasad, S. (2018). Radiologi Diagnostik (2nd ed.). FKUI.

Sandstrom, S. (2011). WHO Manual Pembuatan Foto Diagnostik Teknik \& Proyeksi Radiografi (H. Ostensen \& H. Pettersson (eds.)). Buku Kedokteran EGC.

Whitley, S., Jefferson, G., Holmes, K., Sloane, C., Anderson, C., \& Hoadley, G. (2015). Clark's Positioning in Radiography (13th ed.). CRC Press. 